\title{
Disposition of Intravenous Theophylline in Asthmatic Children: Bayesian Approach vs Direct Pharmacokinetic Calculations
}

\author{
Ehab El Desoky ${ }^{1}$, Mohamed H. Ghazal ${ }^{2}$, Moussa A. Mohamed ${ }^{1}$ and Ulrich Klotz ${ }^{1, \#}$ \\ ${ }^{2}$ Pharmacology and ${ }^{2}$ Pediatric Departments, Faculty of Medicine, Assuit University, 71516 Assuit, Egypt \\ Received February 24, $1997 \quad$ Accepted June 16, 1997
}

\begin{abstract}
Fifteen children (mean age \pm SD: $6.4 \pm 3.4$, range: $2-12$ years) with an acute asthma attack were treated by an intravenous dosage regimen of theophylline ( 30 min loading infusion of $6 \mathrm{mg} / \mathrm{kg}$ body weight followed by a constant infusion of $1 \mathrm{mg} / \mathrm{kg}$, twice for $6 \mathrm{hr}$ each). Three blood samples were drawn (each $15 \mathrm{~min}$ after the bolus infusion and after the two infusion periods of $6 \mathrm{hr}$ ). Plasma clearance (CL), apparent volume of distribution $(\mathrm{Vd})$ and elimination half-life $\left(\mathrm{t}_{1 / 2}\right)$ were estimated by the Bayesian approach using either only the first peak level (Bay 1) or all three monitored concentrations (Bay 3). These values were compared to the parameters calculated by a standard pharmacokinetic procedure (SC). Therapeutic steady state plasma levels around $12 \mu \mathrm{g} / \mathrm{ml}$ were rapidly achieved, and the pharmacokinetic parameters $\left(\mathrm{CL}=1.1-1.5 \mathrm{ml} / \mathrm{min} / \mathrm{kg}, \mathrm{Vd}=0.44-0.501 / \mathrm{kg}, \mathrm{t}_{1 / 2}=3.5-5.4 \mathrm{hr}\right)$ differed slightly between the 3 methods applied. There was a significant linear correlation between the Bayesian-derived and SCderived pharmacokinetic parameters. However the method Bay 1 seems to overestimate the elimination rate of theophylline more than Bay 3 does. In conclusion, Bayesian-based therapeutic plasma level monitoring (Bay 3 are better than Bay 1) can be utilized for individualized pharmacokinetic calculations and proper dosage predictions of theophylline in pediatric patients.
\end{abstract}

Keywords: Theophylline, Pediatrics, Pharmacokinetics, Bayesian

Despite the recognition that asthma is an inflammatory condition of the bronchial mucosa and is not simply caused by smooth muscle spasm, the bronchodilator theophylline still represents an important second line drug for the effective treatment of acute (i.v.-administration) and chronic (mainly oral use) asthma (1-3). It is wellknown that theophylline has a narrow therapeutic index and that both clinical efficacy and adverse reactions (toxicity) are dose-related and dependent on the achieved plasma concentrations $(1,4-6)$. For these reasons, it is very helpful to monitor serum levels of theophylline as guidance for an individualized and optimal therapy $(7,8)$. By such therapeutic monitoring, the influence of endogenous and exogenous effectors on the variable pharmacokinetics of theophylline can also be recognized. Among those endogenous factors, the age of the patients represents a major determinant (9). Whereas most studies have been performed in adults, data in children are still more limited. In older pharmacokinetic studies, theo-

\footnotetext{
* Present address: Dr. Margarete Fischer Bosch Institute of Clinical Pharmacology, 70376 Stuttgart, Germany
}

phylline was infused with a constant rate (Ro) to a steady state (SS), and total body clearance (CL) was calculated by the equation: $\mathrm{CL}=\mathrm{Ro} / \mathrm{Css}$. In 15 infants (age range: $3-23$ month), CL was $1.07 \pm 0.55 \mathrm{ml} / \mathrm{min} / \mathrm{kg}$ (mean \pm S.D.) and the elimination half-life $\left(t_{1 / 2}\right)$ was $4.4 \pm 2.2 \mathrm{hr}(10)$; in 23 children ( $4-15$ years), $\mathrm{CL}$ was $1.35 \pm 0.46 \mathrm{ml} / \mathrm{min} / \mathrm{kg}(11)$; and in 30 children $(6-16$ years), $\mathrm{CL}$ averaged $1.31 \pm 0.54 \mathrm{ml} / \mathrm{min} / \mathrm{kg}$ (12). In all 3 studies, intra-individual variability of $t_{1 / 2}$ (range: $1.4-7.8$ hr; ref. 8) and CL was large. Thus, elimination of theophylline is much faster in children than in adults (ranges of $t_{1 / 2}$ and CL: between $6-10 \mathrm{hr}$ and $0.5-0.9 \mathrm{ml} / \mathrm{min}$ $/ \mathrm{kg}$, respectively). Pharmacokinetic parameters can be also derived from the therapeutic plasma level monitoring data under routine clinical conditions when only a few measured plasma concentrations are available. Different methods and programs have been introduced for these kinetic calculations and individual dosage predictions (13). Among them, the so-called Bayesian approach (14, 15) has been widely accepted and applied (16). In order to generate clinically relevant pharmacokinetic data for the pediatric population, we have used this Bayesian 
approach for theophylline and compared the obtained results with those of a simple pharmacokinetic evaluation.

\section{MATERIALS AND METHODS}

\section{Patient}

Fifteen children (age range: $2-12$ years) with normal liver and kidney function and previous acute attacks of bronchial asthma (allergic type) were admitted to the pediatric department of Assiut University Hospital at night. They were suffering from a typical picture of acute attack of bronchial asthma with dyspnea and cough, and the chest examination showed a wheezy and hyperinflated chest. An x-ray of the chest revealed increased lung markings. The attack occurred on top of an upper respiratory infection, and patients were maintained before on bronchodilator therapy in the form of albuterol (salbutamol) syrup $(2 \mathrm{mg} / 5 \mathrm{ml})$ in a dose of 0.1 $\mathrm{mg} / \mathrm{kg} / \mathrm{dose} / 8 \mathrm{hr}$ before being admitted to the hospital. Selected patients had a positive family history of allergy, and the duration of the disease ranged between 1-4 years. The drug history was taken by asking the parents of the patients to verify that the patients did not receive theophylline by any route of administration for at least one week before the present attack. The individual demographic data are summarized in Table 1.

\section{Study design}

The 15 asthmatic children received aminophylline by a combined intravenous infusion regimen. First a loading dose (LD) of $6 \mathrm{mg} / \mathrm{kg}$ body weight of aminophylline was given as an infusion over $30 \mathrm{~min}$, and a blood sample
Table 1. Demographic data of paediatric patients studied

\begin{tabular}{|c|c|c|c|c|c|c|}
\hline \multirow{2}{*}{ Subject } & \multirow{2}{*}{$\begin{array}{c}\text { Age } \\
\text { (years) }\end{array}$} & \multirow{2}{*}{$\begin{array}{l}\text { Weight } \\
(\mathrm{kg})\end{array}$} & \multirow{2}{*}{$\begin{array}{l}\text { Height } \\
\text { (cm) }\end{array}$} & \multicolumn{3}{|c|}{$\begin{array}{l}\text { Theophylline plasma conc. } \\
(\mu \mathrm{g} / \mathrm{ml})\end{array}$} \\
\hline & & & & $\begin{array}{l}\text { post } \\
\text { loading }\end{array}$ & $6 \mathrm{hr}$ & $12 \mathrm{hr}$ \\
\hline $1\left(0^{x}\right)$ & 2 & 12.0 & 80 & 11.3 & 12.0 & 12.8 \\
\hline $2(9)$ & 2.5 & 12.5 & 85 & 12.8 & 12.5 & 12.3 \\
\hline $3\left(0^{x}\right)$ & 2.5 & 12.3 & 89 & 12.2 & 12.1 & 11.5 \\
\hline $4\left(0^{7}\right)$ & 3.5 & 14.0 & 90 & 12.5 & 13.2 & 14.0 \\
\hline $5(9)$ & 3.5 & 14.2 & 91 & 12.7 & 13.5 & 13.9 \\
\hline $6(9)$ & 5 & 18.5 & 105 & 12.4 & 12.7 & 13.5 \\
\hline $7(9)$ & 5 & 18.0 & 100 & 11.0 & 12.8 & 13.0 \\
\hline $8\left(0^{7}\right)$ & 6.5 & 20.0 & 105 & 10.4 & 12.5 & 13.2 \\
\hline $9(7)$ & 6.5 & 21.0 & 107 & 12.1 & 13.4 & 14.0 \\
\hline $10(9)$ & 7 & 22.0 & 110 & 10.0 & 13.5 & 14.8 \\
\hline $11\left(0^{7}\right)$ & 8 & 23.5 & 115 & 12.5 & 12.9 & 13.2 \\
\hline $12\left(0^{7}\right)$ & 9 & 24.0 & 120 & 9.0 & 11.3 & 13.4 \\
\hline $13\left(0^{7}\right)$ & 11 & 27.0 & 124 & 11.6 & 13.1 & 14.8 \\
\hline $14(\%)$ & 11.5 & 26.8 & 122 & 13.5 & 14.0 & 15.2 \\
\hline $15(0)$ & 12 & 30.0 & 126 & 8.3 & 10.5 & 13.0 \\
\hline mean & 6.4 & 19.7 & 104.6 & 11.5 & 12.7 & 13.5 \\
\hline \pm S.D. & 3.4 & 5.9 & 15.1 & 1.5 & 0.9 & 1.0 \\
\hline
\end{tabular}

was taken 15 min after the end of this infusion to measure the assumed plasma peak level of the drug $\left(C_{1}\right)$. Subsequently, a maintenance dose (MD) was administered as a continuous infusion for $12 \mathrm{hr}$ at an Ro of $1 \mathrm{mg} / \mathrm{kg} / \mathrm{hr}$. Six hours after the start, the infusion was briefly stopped for $15 \mathrm{~min}$, and a second blood sample was taken to monitor plasma theophylline levels $\left(\mathrm{C}_{2}\right)$. The maintenance infusion was continued for another $6 \mathrm{hr}$ and $15 \mathrm{~min}$, and after its end, a third blood sample was drawn and theo-

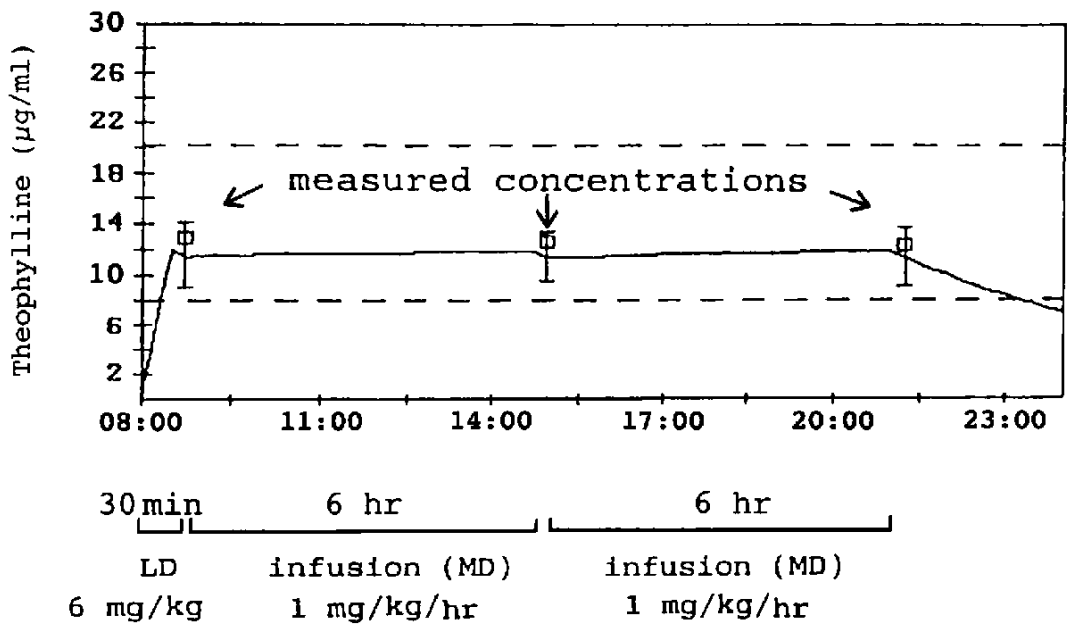

Fig. 1. Schematic diagram of the applied dosage regimen of theophylline, the three measured plasma concentrations of theophylline and its calculated steady concentrations during the constant infusion in one individual patient (\#No. 5). LD: loading dose, MD: maintenance dose. 
phylline was measured $\left(\mathrm{C}_{3}\right)$. This last point could $(12 \mathrm{hr}$ drug level) reflect drug accumulation or may not accurately reflect this drug regimen, especially in the pediatric population who may possibly have non-linear pharmacokinetics. Figure 1 illustrates the protocol of drug administration and blood sampling. Measurement of theophylline plasma concentrations was performed by the Enzyme Multiplied Immunoassay Technique (EMIT) using the Syva EMIT system (Syva Co., Palo Alto, CA, USA). The assay sensitivity was between $2.5-40 \mu \mathrm{g} / \mathrm{ml}$. The precision of the assay was as follows: within the run at $10 \mu \mathrm{g} / \mathrm{ml}$, the coefficient of variation (C.V.) was $5.3 \%$. Between the run at $7.5 \mu \mathrm{g} / \mathrm{ml}, \mathrm{C}$.V. was $4.1 \%$ and at 25 $\mu \mathrm{g} / \mathrm{ml}, \mathrm{C}$.V. was $5.8 \%$.

\section{Pharmacokinetic calculations}

The dose of aminophylline used was corrected to its equivalent theophylline amount (aminophylline contains $86 \%$ anhydrous theophylline). Both $C L$ and volume of distribution $(\mathrm{Vd})$ of theophylline were calculated by the following methods:

1) Bay 1: applying the Bayesian approach (Abbott Pharmacokinetics System; Abbott Diagnostika, Wiesbaden, Germany) taking only $C_{1}$ into account.

2) Bay 3: Bayesian approach taking $C_{1}, C_{2}$ and $C_{3}$ into account for pharmacokinetic calculation.

The calculation of the pharmacokinetic parameters (e.g., $C L, V d, t_{1 / 2}$ ) are based on the open one compartment model.

Concept of Bayesian approach in theophylline pharmacokinetic calculations: Estimation of the likely values of the pertinent pharmacokinetic parameters (e.g., CL, $\mathrm{Vd}, \mathrm{t}_{1 / 2}$ ) of theophylline in the individual patient using the Bayesian approach is based on both specific population pharmacokinetic parameters of theophylline (17) and clinical data of the individual patient (18). The kind of information used by the Abbott Pharmacokinetic Program utilizing the Bayesian approach includes the following:

(1) Clinical status of the patient: age, weight, gender, height, diagnosis and concurrent disease state.

(2) History of drug administration: drug dose, dosage form, route and time of administration, assumed bioavailability (if orally administered).

(3) Time of drug sampling (relative to dose).

(4) Present and previous (if any) plasma drug concentration.

(5) Laboratory data: e.g., renal function (serum creatinine, creatinine clearance) and liver function (serum albumin and bilirubin). In the case of theophylline, about $10 \%$ of the drug is eliminated by renal route.

(6) Concurrent drug therapy (interacting drugs).

(7) Mean values of the population pharmacokinetic parameters of the drug (theophylline in our condition) with their variability.

From all the above data, it is possible to calculate theoretically the expected drug concentration. Then by comparing the expected and actually measured plasma levels of the drug, the pharmacokinetic parameters in individual patients can be assessed and normalized according to the body weight $(\mathrm{kg})$ of the individual patient.

In our case, the Abbott Pharmacokinetic Program started its calculation using the following population data of theophylline adapted for the age group of our patients (17, 18 and personal communication with T.N. Tozer): $\mathrm{CL}=0.09 \pm 0.027 \mathrm{l} / \mathrm{hr} / \mathrm{kg}$ (C.V. $30 \%$ ), $\mathrm{Vd}=0.5 \pm 0.075$ $\mathrm{l} / \mathrm{kg}$ (C.V. $15 \%$ ). Since population data on theophylline shows that clearance is much more variable (large coefficient of variation) than volume of distribution (18), several correcting factors (e.g., 0.4 for congestive heart failure, pneumonia or liver cirrhosis; 0.6 and 1.75 for comedication with cimetidine and phenytoin, respectively; 1.6 for smoking) are implemented in the Abbott kinetic program for calculation of theophylline clearance.

3) Standard pharmacokinetic calculations (SC): The following equations were used based on the dosage regimen and sampling procedure of our study using the 3 measured levels of the drug:
a. $\mathrm{C}_{1}=\frac{\operatorname{Ro}(1)\left(1-\mathrm{e}^{-\mathrm{k} \cdot 0.5}\right) \mathrm{e}^{-\mathrm{k} \cdot 0.25}}{\mathrm{CL}}$
b. $\quad C_{2}=\frac{\left[C_{1} \cdot \mathrm{e}^{-k \cdot 6}+\operatorname{Ro}(2)\left(1-\mathrm{e}^{-\mathrm{k} \cdot 6}\right)\right]}{\mathrm{CL}} \mathrm{e}^{\mathrm{k} \cdot 0.25}$
c. $C_{3}=\frac{\left[C_{2} \cdot \mathrm{e}^{-\mathbf{k} \cdot 6}+\operatorname{Ro}(3)\left(1-\mathrm{e}^{-\mathbf{k} \cdot 6}\right)\right]}{C L} \mathrm{e}^{-\mathbf{k} \cdot 0.25}$

Where: $R o(1)$ is the rate of infusion of LD of the drug (12 $\mathrm{mg} / \mathrm{kg} / \mathrm{hr}$ ); $\operatorname{Ro}(2)$ is the rate of infusion of MD for the first $6 \mathrm{hr}(1 \mathrm{mg} / \mathrm{kg} / \mathrm{hr}$ before second sample); $\mathrm{Ro}(3)$ is the rate of infusion of MD for the remaining $6 \mathrm{hr}$ of theophylline administration $(1 \mathrm{mg} / \mathrm{kg} / \mathrm{hr}$ before the third sample); $K$ is the elimination rate constant and $C L$ is the clearance of theophylline. Equation (a) can be rearranged in terms of CL. The value of CL can then be substituted into equation (b) to give:

$$
\text { d. } C_{2}=\frac{\left[C_{1} \cdot \mathrm{e}^{-\mathrm{k} \cdot 6}+\operatorname{Ro}(2)\left(1-\mathrm{e}^{-\mathrm{k} \cdot 6}\right)\right]}{\operatorname{Ro}(1)\left(1-\mathrm{e}^{-\mathrm{k} \cdot 0.5}\right)} \mathrm{C}_{1}
$$

Using iterative techniques, the value of $\mathbf{K}$ that makes the right hand side of equation (d) equal to the known left hand value $\mathrm{C}_{2}$ can be calculated. Accordingly, $\mathrm{CL}$ of the drug can be determined by rearrangement of any of the first three equations. Subsequently, Vd and $t_{1 / 2}$ of theophylline could be estimated as follows:

$$
\mathrm{Vd}=\mathrm{CL} / \mathrm{K}, \quad \mathrm{t}_{1 / 2}=0.693 \times \mathrm{Vd} / \mathrm{CL}
$$

All the above equations $(a-d)$ were suggested accord- 
Table 2. Individual pharmacokinetic parameters of theophylline in 15 pediatric patients as calculated by 3 different methods

\begin{tabular}{|c|c|c|c|c|c|c|c|c|c|}
\hline \multirow{2}{*}{ Subject } & \multicolumn{3}{|c|}{$t_{1 / 2}(h r)$} & \multicolumn{3}{|c|}{$\mathrm{Cl}(\mathrm{ml} / \mathrm{min} / \mathrm{kg})$} & \multicolumn{3}{|c|}{$\mathrm{Vd}(\mathrm{l} / \mathrm{kg})$} \\
\hline & Bay 1 & Bay 3 & SC & Bay 1 & Bay 3 & $\mathrm{SC}$ & Bay 1 & Bay 3 & $\mathrm{SC}$ \\
\hline 1 & 3.5 & 4.4 & 4.6 & 1.48 & 1.17 & 1.23 & 0.44 & 0.44 & 0.49 \\
\hline 2 & 3.1 & 4.0 & 4.1 & 1.46 & 1.12 & 1.22 & 0.39 & 0.39 & 0.43 \\
\hline 3 & 3.1 & 4.0 & 3.9 & 1.45 & 1.14 & 1.32 & 0.40 & 0.40 & 0.45 \\
\hline 4 & 3.2 & 4.4 & 4.4 & 1.46 & 1.05 & 1.16 & 0.40 & 0.40 & 0.44 \\
\hline 5 & 3.1 & 4.4 & 4.3 & 1.40 & 1.04 & 1.16 & 0.40 & 0.39 & 0.43 \\
\hline 6 & 3.3 & 4.3 & 5.0 & 1.47 & 1.08 & 1.04 & 0.41 & 0.41 & 0.45 \\
\hline 7 & 3.6 & 4.6 & 5.1 & 1.50 & 1.17 & 1.14 & 0.47 & 0.46 & 0.55 \\
\hline 8 & 3.8 & 4.7 & 6.1 & 1.50 & 1.17 & 1.04 & 0.49 & 0.48 & 0.55 \\
\hline 9 & 3.5 & 4.4 & 5.1 & 1.49 & 1.52 & 1.05 & 0.45 & 0.45 & 0.46 \\
\hline 10 & 3.9 & 5.2 & 9.2 & 1.50 & 1.09 & 0.73 & 0.51 & 0.49 & 0.58 \\
\hline 11 & 3.4 & 4.2 & 4.8 & 1.48 & 1.17 & 1.08 & 0.43 & 0.43 & 0.45 \\
\hline 12 & 3.9 & 5.2 & 4.6 & 1.50 & 1.11 & 1.55 & 0.51 & 0.50 & 0.62 \\
\hline 13 & 3.5 & 4.8 & 6.3 & 1.48 & 1.05 & 0.90 & 0.44 & 0.44 & 0.49 \\
\hline 14 & 3.2 & 4.4 & 5.8 & 1.46 & 1.07 & 0.84 & 0.41 & 0.41 & 0.42 \\
\hline 15 & 4.4 & 5.2 & 7.7 & 1.50 & 1.25 & 1.06 & 0.57 & 0.56 & 0.70 \\
\hline $\begin{array}{l}\text { mean } \\
\pm \text { S.D. }\end{array}$ & $\begin{array}{l}3.5^{*} \\
\pm 0.4\end{array}$ & $\begin{array}{r}4.5 \\
\pm 0.4\end{array}$ & $\begin{array}{r}5.4 \\
\pm 1.4\end{array}$ & $\begin{array}{l}1.48^{*} \\
\pm 0.02\end{array}$ & $\begin{array}{r}1.15 \\
\pm 0.12\end{array}$ & $\begin{array}{r}1.10 \\
\pm 0.20\end{array}$ & $\begin{array}{r}0.45 \\
\pm 0.05\end{array}$ & $\begin{array}{r}0.44 \\
\pm 0.05\end{array}$ & $\begin{array}{r}0.50 \\
+0.08\end{array}$ \\
\hline
\end{tabular}

SC: Pharmacokinetic calculations according to equations a- $\mathrm{d}$ as suggested by T.N. Tozer (personal communication). ${ }^{*} \mathrm{P}<0.05$ (paired Student's $t$-test) in comparison to their corresponding SC values.

ing to the literature (18) by Dr. T.N. Tozer. Since this procedure calculated the pharmacokinetic parameters of each patient independent of the population data of theophylline, it was considered as a kind of standard method. The results of all three calculations (SC, Bay 1, Bay 3) were compared and tested for correlations by linear regression analyses. For all statistical calculations, the SPSS statistical program (Windows version 3.1) was used.

\section{RESULTS}

With the applied dosage regimen $(6 \mathrm{mg} / \mathrm{kg}$ as an $\mathrm{LD}$ infusion in $30 \mathrm{~min}$ followed by $1 \mathrm{mg} / \mathrm{kg} / \mathrm{hr}$ as an MD infusion for $12 \mathrm{hr}$ ), stable steady state concentrations of theophylline (around $13 \mu \mathrm{g} / \mathrm{ml}$ ) within the therapeutic range $(8-20 \mu \mathrm{g} / \mathrm{ml})$ were rapidly achieved (see Fig. 1 and Table 1).

The individual and mean ( \pm S.D.) values of $t_{1 / 2}, C L$ and $\mathrm{Vd}$ calculated by the three methods are listed in Table 2. Apparently, the Bayesian approach (especially if only 1 point was used) underestimated $t_{1 / 2}$ and overestimated $C L$ as those values significantly differed from the SC. Nevertheless, significant $(\mathrm{P}<0.01)$ linear correlations could be observed between the $C L$ values calculated by the 3 methods (see Fig. 2). Likewise, significant relationships were found for the calculated $\mathrm{Vd}$ and $t_{1 / 2}$ values (see Figs. 3 and 4).
We have tried to assess prediction performance of the Bay 1 and Bay 3 approaches according to Sheiner and Beal (19) regarding the $\mathrm{SC}$ as the reference values (Table 3 ). The mean prediction error (me) indicated that there was some minimal overestimation of $\mathrm{CL}(0.372$ and $0.045 \mathrm{ml} / \mathrm{min} / \mathrm{kg}$ ) and some underestimation of $\mathrm{Vd}$ $(-0.029$ and $-0.044 \mathrm{l} / \mathrm{kg})$ by both Bayesian methods. Precision as measured by the root mean squared prediction error (rmse) was comparable between Bay 1 and Bay 3 , but in general performance for calculation of CL, Bay 3 was better than Bay 1 .

\section{DISCUSSION}

Theophylline is still one of the most common bronchodilators for pediatric use in Assiut University Hospital to treat acute asthma. An LD of theophylline followed by a constant i.y. infusion usually provides a greater bronchodilator effect than intermittent i.v. therapy that may cause wide fluctuations of the drug level in the blood. The bronchodilator effect of theophylline is dependent on its serum free concentration, and such fluctuations can affect the clinical response $(1-8,20)$. The dosage regimen applied in our study (LD: $6 \mathrm{mg} / \mathrm{kg}$, i.v. in $30 \mathrm{~min}$ followed by an MD infusion of $1 \mathrm{mg} / \mathrm{kg} / \mathrm{hr}$ for $12 \mathrm{hr}$ ) is similar to that recommended in the literature $(1,21-23)$. By this procedure, a steady state plasma level of theophylline within the accepted therapeutic range of the drug was 
A

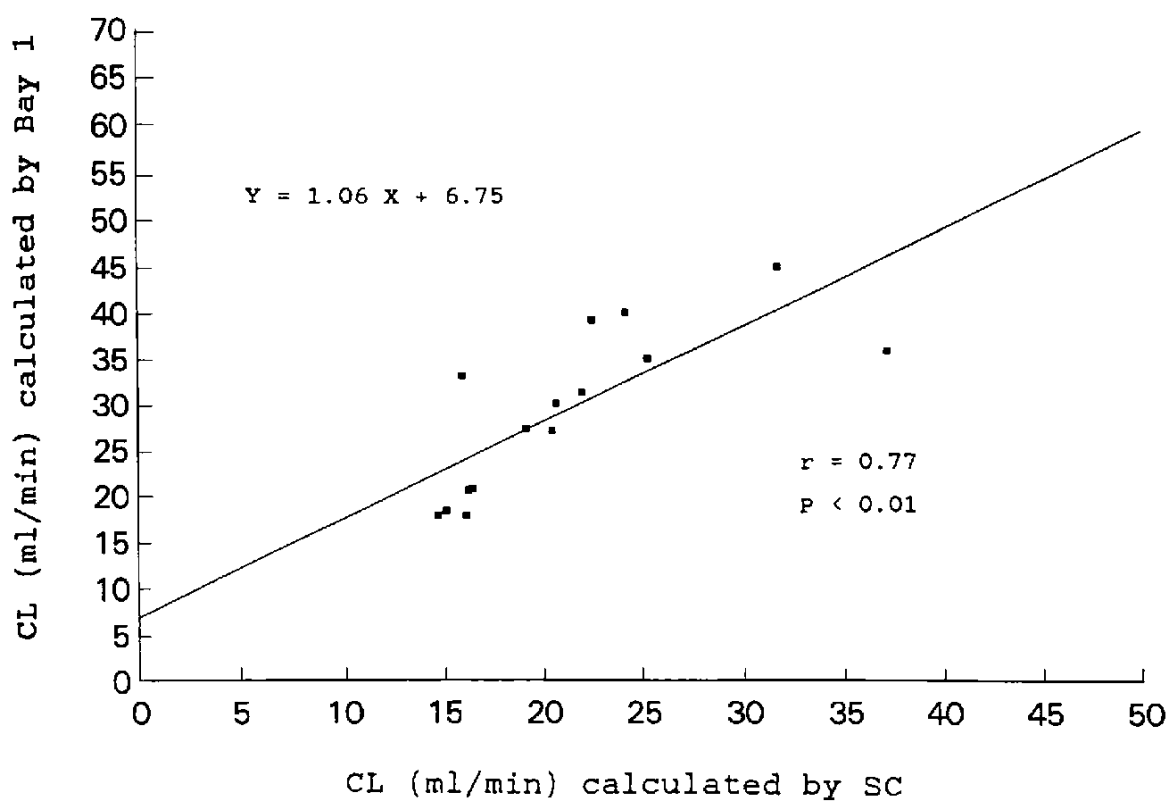

B

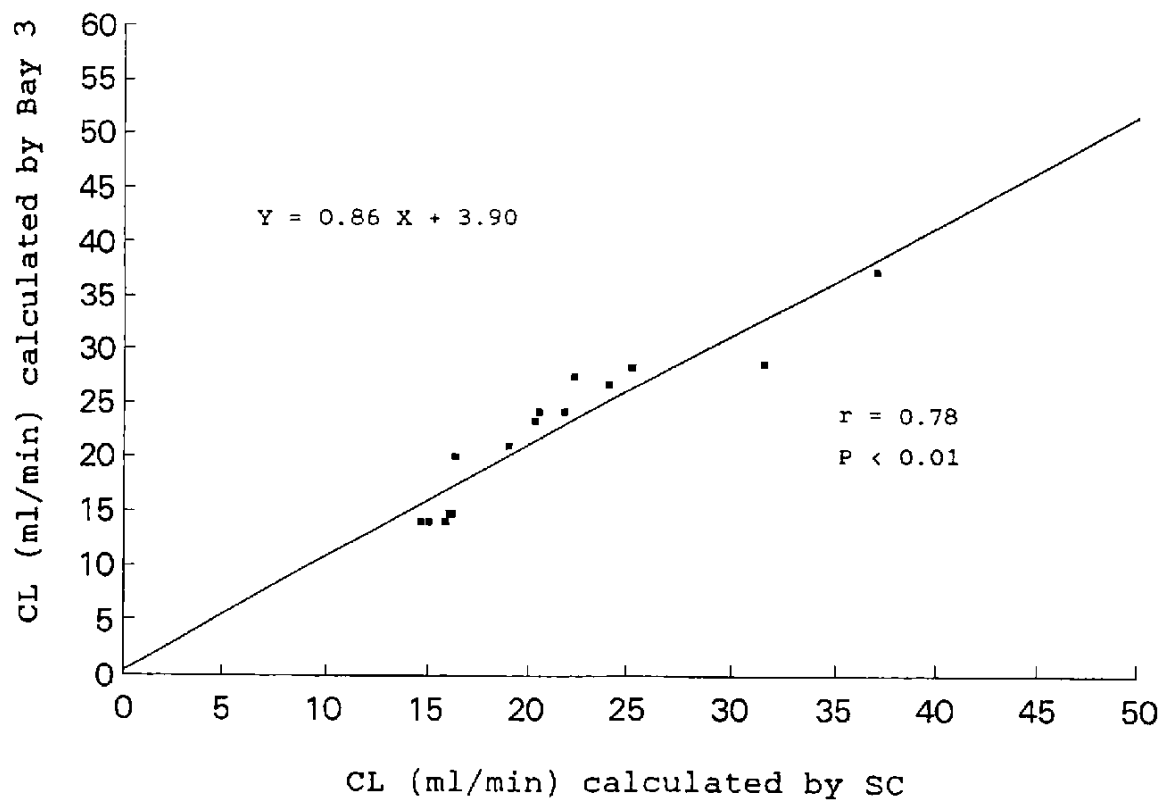

Fig. 2. Linear regression analysis of the individual CL values of theophylline as calculated by two different methods. A: Standard pharmacokinetic calculations (SC) vs Bayesian approach (Bay 1). B: SC vs Bayesian approach (Bay 3).

rapidly achieved (see Fig. 1 and Table 1). The estimated values of $\mathrm{Vd}$ in our patients (irrespective of the method of calculation) were within the population range reported for theophylline $(0.3-0.7 \mathrm{l} / \mathrm{kg})$ in children and adults $(10-12,21-25)$. The excellent correlation $(r=0.97)$ of Vd values calculated by SC versus either Bay 1 or 3 may partly be attributed to the i.v. route of administration of theophylline where factors that may cause variability in kinetic calculations of theophylline, e.g., rate and extent of absorption, were excluded.

It is well-known that theophylline is one of the popular drugs that are characterized by large interpatient variability in its rate of elimination (9). For instance, as children clear theophylline more rapidly than adults, usually larger amounts of the drug are needed in this population (8). In the present study, CL estimated by SC $(1.1 \pm 0.2$ 

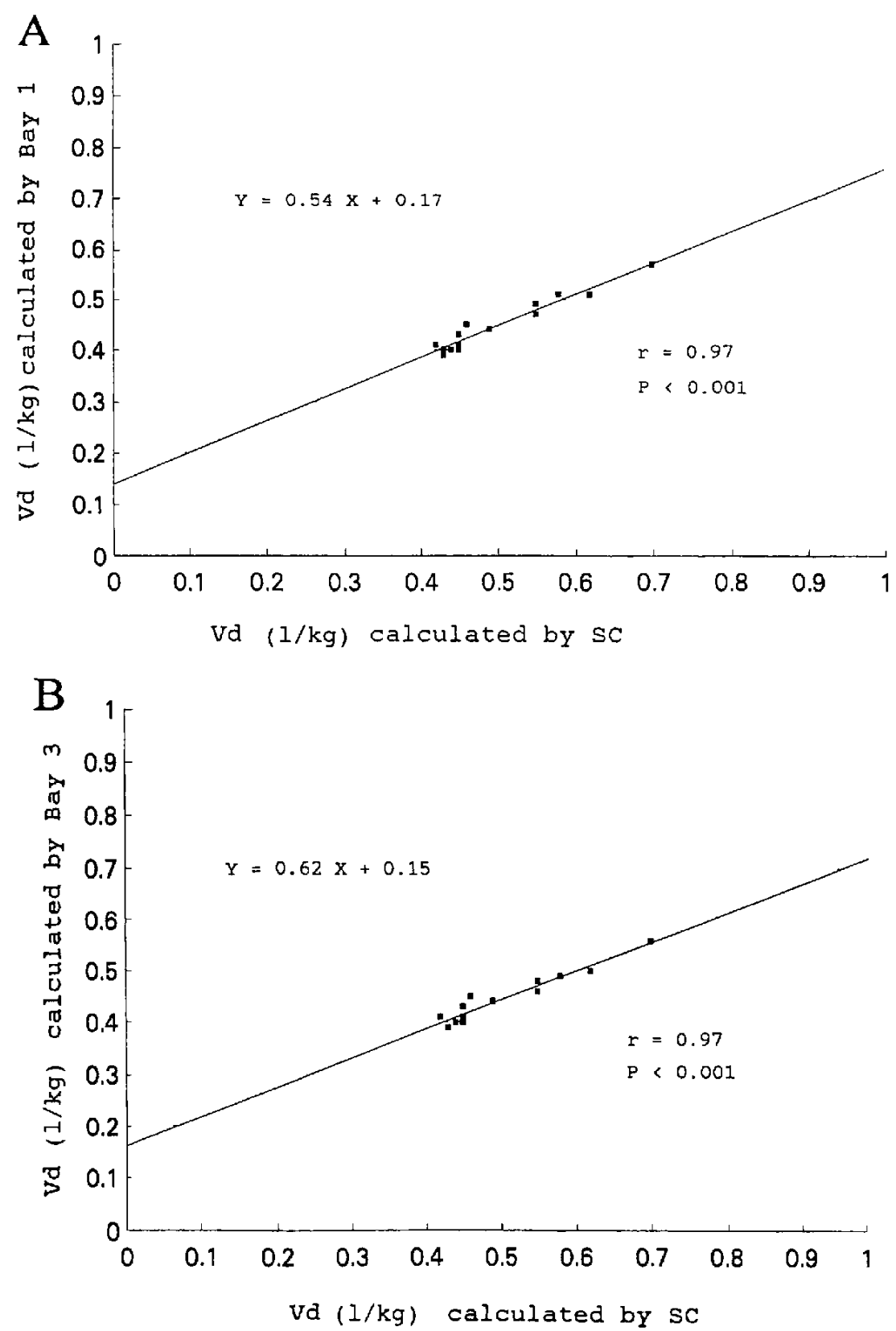

Fig. 3. Linear regression analysis of the individual Vd values of theophylline as calculated by two different methods. A: Standard pharmacokinetic calculations (SC) vs Bayesian approach (Bay 1). B: SC vs Bayesian approach (Bay 3).

$\mathrm{ml} / \mathrm{min} / \mathrm{kg}$ ) was slightly lower than the literature values $(11,12)$. This probably reflects the wide intra- and interindividual variability in the hepatic elimination even in similar age groups (22). The CL value in our population (2-12 years) averaged $1.48 \mathrm{ml} / \mathrm{min} / \mathrm{kg}$ when estimated by Bay 1 , which is slightly higher if compared to the literature data $(11,12): 1.35 \pm 0.46 \mathrm{ml} / \mathrm{min} / \mathrm{kg}(\mathrm{n}=23$, $4-15$ years) and $1.31 \pm 0.54(n=30,6-16$ years $)$. Also, the Bay $1 \mathrm{CL}$-value was overestimated in comparison to either SC or Bay 3 methods (Table 2). This may be ascribed to the fact that in Bay 1, the single sample taken after the LD (as used in this method), gives little information about the variable of CL. Therefore, the population mean value will dominate, and the calculated clearance was obviously higher than the true clearance values in our patients. On the other hand, the CL value calculated by the Bay 3 method of $1.15 \mathrm{ml} / \mathrm{min} / \mathrm{kg}$ is slightly lower than those in the literature, but comes closer to the true CL value of $1.1 \mathrm{ml} / \mathrm{min} / \mathrm{kg}$ (SC) of our patients. In this condition, the sample taken at $7 \mathrm{hr}$ from the begin- 

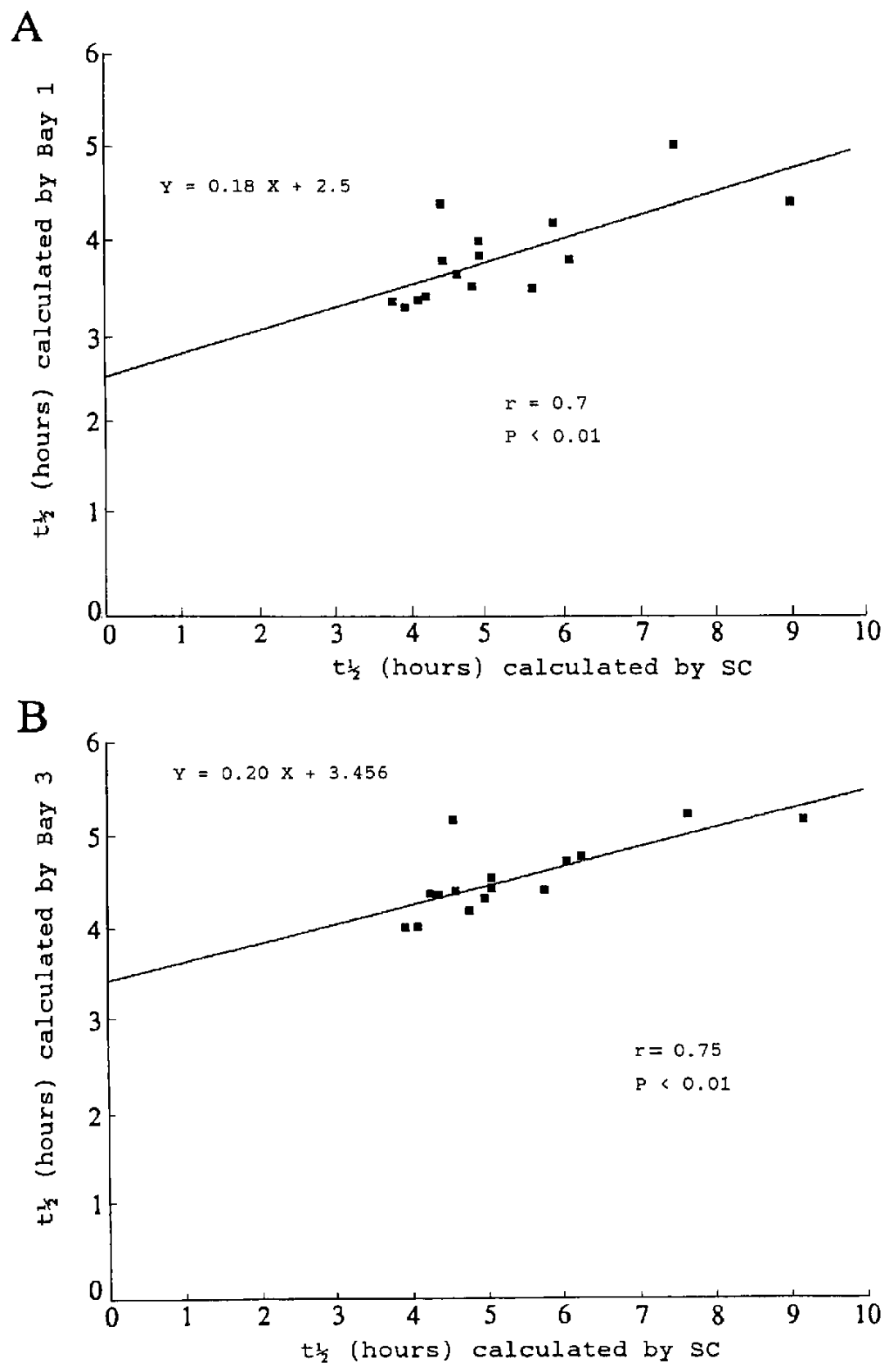

Fig. 4. Linear regression analysis of the individual $t_{1 / 2}$ values of theophylline as calculated by two different methods. A: Standard pharmacokinetic calculations (SC) vs Bayesian approach (Bay 1). B: SC vs Bayesian approach (Bay 3).

Table 3. Performance evaluation of pharmacokinetic parameters of theophylline by two different methods

\begin{tabular}{|c|c|c|c|c|}
\hline \multirow{2}{*}{ Kinetic parameter } & \multicolumn{2}{|c|}{ Bay 1} & \multicolumn{2}{|c|}{ Bay 3} \\
\hline & me & rmse & me & rmse \\
\hline $\begin{array}{l}\mathrm{CL}(\mathrm{ml} / \mathrm{min} / \mathrm{kg}) \\
95 \% \text { confidence intervals }\end{array}$ & $\begin{array}{c}0.372 \\
0.259 \text { to } 0.485\end{array}$ & $\begin{array}{c}0.421 \\
0.299 \text { to } 0.515\end{array}$ & $\begin{array}{c}0.045 \\
-0.081 \text { to } 0.171\end{array}$ & $\begin{array}{c}0.224 \\
0.103 \text { to } 0.299\end{array}$ \\
\hline $\begin{array}{l}\mathrm{Vd}(1 / \mathrm{kg}) \\
95 \% 0 \text { confidence intervals }\end{array}$ & $\begin{array}{c}-0.029 \\
-0.054 \text { to }-0.004\end{array}$ & $\begin{array}{c}0.052 \\
0.030 \text { to } 0.066\end{array}$ & $\begin{array}{c}-0.044 \\
-0.065 \text { to }-0.022\end{array}$ & $\begin{array}{c}0.066 \\
0.036 \text { to }-0.087\end{array}$ \\
\hline
\end{tabular}

me: mean prediction error (measure of bias), rmse: root mean squared prediction error (measure of precision). 
ning of drug administration $\left(\mathrm{C}_{2}\right)$ gives the best information on CL. Given that an LD is used and that $t_{1 / 2}$ of the drug is about $5 \mathrm{hr}$, steady state will be achieved in most subjects already after the first $6 \mathrm{hr}$ of infusion. Apparently, the Bay 1 method overestimates CL in our data set, and Bay 3 would be preferable. This is not surprising as current evidence provided by 3 available concentrations will achieve a better precision (13).

In general, the present study demonstrated that the Bayesian approach utilizing one or three plasma drug levels provides a better agreement with $\mathrm{SC}$ for pharmacokinetic parameters of theophylline (especially for $\mathrm{Vd}$ values) when the drug is administered i.v. if compared to similar studies carried out with orally sustained release preparations for theophylline in adults (16). The variability in the rate and extent of absorption of sustaineed release preparations of theophylline may explain this discrepancy.

In conclusion, the drug regimen of theophylline used among our patients as a $6 \mathrm{mg} / \mathrm{kg}$, i.v. $\mathrm{LD}$ followed by a 1 $\mathrm{mg} / \mathrm{kg}$, i.v. maintenance infusion could achieve a plateau plasma level of theophylline within the therapeutic range and at the same time correlate better with the relief of symptoms of bronchial asthma in pediatric patients. In addition, plasma level monitoring ( 3 levels are better than single drug concentration) in combination with Bayesian statistics provide sufficient information about clearance of theophylline and consequently dosage optimization and modification when the drug is used intravenously in pediatric patients.

\section{Acknowledgment}

We express our sincere thanks to Prof. T.N. Tozer, School of Pharmacy, University of California for his suggestion of the pharmacokinetic model (SC) used in our study. This study was partly supported by Robert Bosch Foundation, Stuttgart, Germany.

\section{REFERENCES}

1 Mitenko PA and Ogilvie RI: Rational intravenous doses of theophylline. N Engl J Med 289, 600-603 (1973)

2 Weinberger MM: Theophylline. Immunol Allerg Clin North Am 10, 559-576 (1990)

3 Frew AJ and Holgate ST: Clinical pharmacology of asthma. Implications for treatment. Drugs 46, 847-862 (1993)

4 Woodcock AA, Johnson MA and Geddes DM; Theophylline prescribing, serum concentrations and toxicity. Lacent II, $610-613(1983)$

5 Chrystyn H, Mulley BA and Peake MD: Dose response relation to oral theophylline in severe chronic obstructive airways disease. Br Med J 297, 1506-1510 (1988)

6 Holford N, Black P, Couch R, Kennedy J and Briant R: Theophylline target concentration in severe airways obstruction10 or $20 \mathrm{mg} / \mathrm{L}$ ? A randomised concentration-controlled trial. Clin Pharmacokinet 25, 495-505 (1993)
7 Ashutosh K, Bajaj R, Cho C and Sangani G: Use of serum theophylline level as a guide to optimum therapy in patients with chronic obstructive lung disease. J Clin Pharmacol 30, 324-329 (1990)

8 Bierman CW and Williams PV: Therapeutic monitoring of theophylline. Rational and current status. Clin Pharmacokinet 17, $377-384$ (1989)

9 Troger $U$ and Meyer F: Influence of endogenous and exogenous effectors on the pharmacokinetics of theophylline. Clin Pharmacokinet 28, 287-314 (1995)

10 Simons FER and Simons KJ; Pharmacokinetics of theophylline in infancy. J Clin Pharmacol 18, 472-476 (1978)

11 Ginchansky E and Weinberger M: Relationship of theophylline clearance to oral dosage in children with chronic asthma. Pediatr Pharmacol Ther 91, 655-660 (1977)

12 Leung P, Kalisker A and Bell TD: Variation in theophylline clearance rate with time in chronic childhood asthma. J Allergy Clin Immunol 59, 440-444 (1977)

13 Erdman SM, Rodvold KA and Pryka RD: An updated comparison of drug dosing methods. Part II: Theophylline. Clin Pharmacokinet 20, 280-292 (1991)

14 Sheiner LB and Beal SL: Bayesian individualization of pharmacokinetics: simple implementation and comparison with non-Bayesian methods. J Pharm Sci 71, 1344-1348 (1982)

15 Thomson $\mathrm{AH}$ and Whitting B: Bayesian parameter estimation and population pharmacokinetics. Clin Pharmacokinet 22, 447-467 (1992)

16 El Desoky E, Meinshausen J, Buhl K, Engel G, Harings-Kaim A, Drewelow B and Klotz U: generation of pharmacokinetic data during routine therapeutic drug monitoring: Bayesian approach vs. pharmacokinetic studies. Ther Drug Monit 15, $281-288$ (1993)

17 Evans WE, Schentag JJ and Jusko WJ: Applied Pharmacokinetics: Principles of Therapeutic Drug Monitoring, 3rd edition, Applied Therapeutics Inc, Vancouver (WA) (1992)

18 Rowland M and Tozer TN: Clinical Pharmacokinetics. Concepts and Applications, 3rd edition, Lea \& Febiger, Philadelphia and London (1995)

19 Sheiner LB and Beal SL: Some suggestions for measuring predictive performance. J Pharmacokinet Biopharm 9, $503-512(1981)$

20 Goldberg P, Leffert F, Gonzalez H, Gogenola L and Zerbe GO: Intravenous aminophylline therapy for asthma. $\mathrm{A}$ comparison of two methods of administration in children. Am J Dis Child 134, 596- 599 (1980)

21 Hendeles L, Weinberger M and Bighley L: Disposition of theophylline following a single intravenous aminophylline infusion. Am Rev Respir Dis 118, 97-103 (1978)

22 Hendeles L and Weinberger M: Theophylline a "state of the art" review. Pharmacotherapy 3, 2- 44 (1983)

23 Kubo M, Odajima $Y$, Ishizaki $T$, Kanagawa S, Yamaguchi M and Nagai T: Intraindividual chages in theophylline clearance during constant aminophylline infusion in children with acute asthma. J Pediatr 108, 1011 - 1015 (1986)

24 Mitenko PA and Ogilvie RI: Pharmacokinetics of intravenous theophylline. Clin Pharmacol Ther 14, 509-513 (1973)

25 Ellis E, Koyosooko R and Levy G: Pharmacokinetics of theophylline in children with asthma. Pediatrics 58, 542-547 (1976) 